\title{
Assessment, Development and Deployment of Innovative Services
}

\author{
Martin Tschandl, Herbert Michael Richter, Christian Bischof* \\ Institute of Industrial Management, FH JOANNEUM University of Applied Sciences, Kapfenberg, Austria

\section{Email address:} \\ martin.tschandl@fh-joanneum.at (M. Tschandl), herbertmichael.richter@fh-joanneum.at (H. M. Richter), \\ christian.bischof@fh-joanneum.at (C.Bischof) \\ ${ }^{*}$ Corresponding author
}

\section{To cite this article:}

Martin Tschandl, Herbert Michael Richter, Christian Bischof. Assessment, Development and Deployment of Innovative Services. International Journal of Science, Technology and Society. Vol. 6, No. 1, 2017, pp. 17-24. doi: 10.11648/j.ijsts.20180601.14

Received: October 10, 2017; Accepted: November 1, 2017; Published: January 17, 2018

\begin{abstract}
Products are becoming gradually similar and thus, interchangeable due to the global convergence of producers and consumers, as well as the increasing homogeneity of product attributes and technologies. Differentiation merely by products has become highly complex and difficult. One potential solution for restoring or strengthening differentiation in the market is doing so by means of expanding existing products with specially tailored services (hybrid products) in order to achieve a sustainable, competitive advantage. The purpose of this paper is to address the major topics related to the assessment, development and deployment of innovative services in theory and practice as well as to underline the importance of digitisation for the development of such services. Hence, a thorough discussion of the concept of Service Engineering is a key feature of this paper. Additionally, the status of service development in Austrian companies has been assessed. A six-step maturity model is introduced, allowing the assessment of the current status quo as well as the target-setting. Furthermore, a procedure model for developing and implementing innovative services is presented.
\end{abstract}

Keywords: Innovative Services, Service Engineering, Digitisation, Maturity Model, Procedure Model

\section{Introduction}

According to traditional concepts of strategic management, a competitive advantage comes from innovative and/or highly sophisticated technological solutions. However, as quality and technologies have become aligned and largely homogenous, today's products are increasingly similar and therefore, interchangeable for customers. Additionally, a growing number of producers from low-cost regions are able to produce at quality levels comparable to European standards. Consequently, it is nearly impossible for many companies to differentiate themselves from competitors merely in terms of their products or services [1] [2]. One potential solution to this strategic dilemma consists of expanding the existing product range with innovative, customised services, thus, re-establishing an economically sustainable competitive advantage [3] [4] [5].

This article shall provide answers to the questions as to what extent Service Engineering can support the development and deployment of innovative services, and how digitisation may leverage the development of such services. A six-step maturity model allows companies to classify their service portfolios and therefore, to determine their current status quo. Additionally, companies can set targets to expand their portfolios by developing services to the next level. Finally, a service procedure model is presented, which has been developed in cooperation with partners from the mechanical and plant engineering industry, logistics and service providers, and universities. The model consists of several different stages: firstly, by starting or enlarging the range of services which could be useful for customers; secondly, by establishing a systematic process for identifying customer-specific requirements and needs; thirdly, by the integration of products and specially developed services. 


\section{Method}

\subsection{Systematic Conceptual Approach}

The development of new services should not be the result of an accidental or random process. Rather, a systematic approach to the effective and efficient development of services is required. One of these approaches is Service Engineering, which aims at utilising engineering know-how to release the hidden potential of service processes [6] [7]. Based on a differentiation strategy and a holistic understanding of services, Service Engineering comprises aspects like service management, marketing and customer-oriented evaluation and the application of methods of industrial quality management. This leads to an accelerated rate of innovation and quality of services, resulting in a competitive advantage. In order to constantly create new service offers, the concept of Service Engineering is being continuously expanded. By considering the opportunities arising from the progressing digitisation of industrial processes, the engineering-based concept of Service Engineering should be enriched by creative aspects like Design Thinking [8] [9]. This could lead to the development of innovative service solutions that entail entirely new business processes. Consequently, Service Engineering allows for the creation, implementation and continuous advancement of services and service solutions by applying a framework of interdisciplinary, strategic and creative processes, as well as a staged procedure model. As a result, this contributes to a "value-driven corporate development" [10].

By applying this systematic approach, a hybrid package of products and services can be created in a design and development process. This process focusses on fulfilling customer needs, thus, it generates additional value for the customer [11]. Furthermore, modern billing models such as pay per use, pay per hour or pay per piece, can be established. This strategic approach - integrating a hybrid package of products and services - accompanied by modern billing models, leads to a sustainable unique selling proposition in today's highly competitive global markets, and consequently, to greater profitability.

Besides strategic differentiation, applying the basic approach, tools and methods of Service Engineering leads to additional benefits for a business. As customer needs and requirements are recognised in a timely manner, and are incorporated in the problem-solving process, this should lead to greater customer satisfaction. Furthermore, quality of service improves by the implementation of specific tools and methods (e.g. testing services). Internally, the systematic and efficient development of services leads to a reduction in development costs and shortens the time to market. Additionally, fewer aberrations and improved success rates of innovation can be realised by testing services at an early stage and managing customer integration during the development process [12] [13] [14].

\subsection{Empirical Survey}

Intensive efforts to optimise processes along the entire value chain have already led to significant improvements in terms of effectiveness and efficiency. In order to generate additional revenue and profit, new or revised concepts in terms of strategic management and supply chain management are required. These concepts should emphasise customer needs. Initial approaches to innovate services considering customer needs have already become apparent in many companies. In order to gain a better understanding of the current state of development of services in Austrian companies, FH JOANNEUM conducted a survey in cooperation with FH Oberösterreich Steyr. An online questionnaire was sent to Austrian companies operating in the sectors of mechanical engineering and plant engineering, logistics providers and automotive suppliers, which was answered by 118 companies. The initial research question of the survey was whether and to what extent the development of new services had been embedded within both the corporate strategy and the organisational structure. Additionally, the survey should reveal which stakeholders are involved in a service development process and which obstacles currently exist. The major results of this survey are presented in the following passages [10].

\section{Results}

\subsection{Current State of Service Development}

According to the results of the survey, more than $80 \%$ of the companies interviewed acknowledge service development as a part of their long-term planning strategy. However, just under $50 \%$ of the interviewed companies do not even have a written strategy for the development of new services. Within a company, the sales department is said to be the most involved corporate function according to $25 \%$ of the answers. Less involved functions/departments include procurement, logistics, management accounting or quality management.

Furthermore, the research study focussed on the specific shapes of service development processes in business practice, e.g. by asking how and how frequently ideas for services are initiated. Half (51\%) of the interviewed companies stated that the service development process is often or very often triggered by customer requirements and claims. Similar degrees of significance are attributed to staff (49\%) and technological developments $(41 \%)$. Other relevant triggers for the development process of new services are stimuli that come from the network and customer surveys, whereas external partners only play a minor role in initiating the innovation process. In addition to these trigger events, tenders, competitive analysis, developments of market players, a systematic analysis of service innovations in other sectors, findings from R\&D, as well as the implementation of new technologies in existing plants are cited as further initial factors for the development of new services.

Regarding the application of procedure models in business practice the survey revealed that in $33 \%$ of the companies, no defined process for the development of (innovative) services 
exists. A quarter of the companies questioned apply a linear phase model and conduct the individual phases successively and chronologically. Further $21 \%$ use the prototype model as guide; $15 \%$ of the respondents make use of a cyclical model, whereby the development phases are run through several times. Furthermore, we can conclude from the findings of the survey that only $32 \%$ of companies have formally documented the service development process. In contrast, $27 \%$ of the companies have no documentation whatsoever in place and the development process is only regulated to a minimal degree in $41 \%$ of the responding companies.

Another part of the survey concerned networking activities and analysed specifically the relationship towards suppliers, customers and other partners. The respondents' opinion is that service developments are fostered by active cooperation between companies and their customers. Additionally, new service developments of the competitors should be analysed to push own developments. Moreover, transparency and communication within the network are important for the surveyed companies, while, a close relationship with consultancy firms or knowledge transfer within the network is not seen as being particularly significant.

Finally, the survey aimed at gaining a better understanding to what extent companies react to changes in their business environment regarding new services. Initially, the future relevance of approaches for expanding services in a company was analysed. $69 \%$ of the companies surveyed mainly see generating turnover from new or existing customers as highly relevant. Equally, 65\% consider an increased value of service offers as significant, as do $63 \%$ regarding the range of product and service offers [10].

\subsection{Trends and Challenges in Service Development}

The extent of change in the range of services during the next three years is expected to be substantial. Most companies believe in expanding and developing their range of services; some even have active plans to do this. On the one hand, $78 \%$ of companies are developing current services in existing markets and $77 \%$ are creating new concepts. On the other hand, $64 \%$ of the surveyed companies are developing current services for new markets, while $51 \%$ are currently devising new service concepts [10].

The research study also revealed that corporate targets with respect to services range from "hard" to "soft" targets. Hard targets consist of a closer cooperation with customers in the early phases of the service development process, the increase of customer-self-service offerings based on digital technologies and the standardisation of hybrid products. Examples for soft targets are creating and heightening customer enthusiasm, providing full-service-offerings to the customer and increasing the (positive) perception of services mainly on the customer's side but also from the provider's point of view.

With regard to future trends, the majority of companies consider services an essential part of their future portfolio. Around $50 \%$ of the companies expect the portion of service revenue to grow to more than $40 \%$ of their total revenue.
However, only $24 \%$ of the companies surveyed have set up a separate unit for service development [10].

Additionally, many companies still face major challenges in the systematic development of new services. Over a third $(38 \%)$ of the interviewees confirmed that they prioritised day-to-day business and that this is the most common reason why the development of services faces constraints, whereas $33 \%$ face budgetary challenges. Another major challenge is the insufficient training and education of staff $(27 \%)$, resulting in a weak knowledge base for developing innovative services especially when it comes to digital technologies.

\section{Discussion}

\subsection{Digital Service Innovations}

Due to the rapid rate of digitisation, industrial machines and plants are increasingly being equipped with digital components and data connections to internal and external networks. Consequently, new possibilities are to promote innovative services constantly emerging with the aid of these new advancements in technology. Digital technologies will fundamentally change services in the imminent future. Among others, Big Data, the use of service apps, recommendation engines and Augmented Reality are widely considered as being of high relevance for future innovative services [15].

According to the European Technology Platform for Industry and Science, the term Big Data is defined as "the use of techniques to capture, process, analyse and visualise potentially large datasets in a reasonable timeframe not accessible to standard IT technologies" [16]. Big Data enables the collection and use of structured as well as unstructured data from various internal and external sources, which is available in a previously unknown and unprecedented quantity [17]. Through the analysis of usage data customer-specific and proactive services can be provided. Examples for benefits in this area are the early detection of product quality problems and a preventive and individualised maintenance [18]. Smart products like connected machines provide manufacturers with data regarding utilisation intensity and failure probability that can be utilised for an efficient planning of maintenance leading to a higher availability, an improved cost-benefit ratio and higher customer satisfaction [19] [20].

Service apps are based on internet technology and programming solutions. Service divisions of manufacturing companies are becoming increasingly involved in working with apps and portals to further develop their service business. Apps can be used for a wide range of service solutions. They include the documentation of service deployments, providing information on machines (e.g. instruction manuals) or customer apps for reporting faults and errors. The major advantage, leading to a high user acceptance of apps, is explained by the fact that apps are easier to set up and their menu navigation is largely self- 
explanatory compared to desktop solutions [15].

Recommendation engines are selection processes which render automated recommendations, based on data mining. This technology has reached the highest maturity level in technical sales, where a certain sales support is necessary in terms of features of the respective products or services. In principle, this technology is also relevant for providing support for various service processes. For instance, customer-specific usage parameters, like downtimes, machine operation times and performance indicators for wear, can be recorded by service configurators. These systems are also able to calculate and recommend the optimal services and service contract for a given customer, based on comparable data [15].

The term "Augmented Reality" stands for the computeraided expansion of the perception of the given reality. Real objects and virtual objects or pieces of information are merged simultaneously. There is an expectation for great things to come from Augmented Reality solutions, particularly in the field of technical services. "The new assistance systems, in short Assist 4.0, are going to revolutionise the way in which production and service staff is to be utilised", the company KNAPP is quoted on its website [21]. Knapp is supporting its technicians with the help of virtual instructions during maintenance and repair work. Both hands should remain free during process execution by using data glasses.

\subsection{Service Maturity Model}

Rapid progress in digital technologies, in conjunction with rising complexity and an increased range of services on the market, leads to higher requirements regarding companies' capabilities for delivering hybrid products. Thus, it is necessary to have a certain maturity in developing and deploying services.
In general, maturity can be described as "an evolutionary progress in the demonstration of a specific ability or in the accomplishment of a target from an initial to a desired or normally occurring end stage" [22]. In recent years, an increasing interest in maturity models has been identified in both theory and practice. Maturity models are used in various fields like project management, quality management, change management, business process management, sustainability or supply chain management. Depending on the field of application different questions can be answered, e.g. "Where are we now?", "Where do we want to get to?" or "What are the various steps along the way and how will we know when we have reached the required destination?".

Like in any other field, maturity models for services are applied as an instrument to assess the current status and to define goals. Companies can assess their position within the model (status) and expand their portfolio with services from a level that is higher up in structure (goals) [6] [23]. It is recommended to evolve through the model step by step, as more advanced maturity levels principally build on the organisational capabilities and competences of the lower levels [6].

This is also the underlying logic of the maturity model for services, using the example of machine and plant engineering as illustrated in Figure 1 and described in the following passage [24]. It is divided into six levels, whereby level 0 basically does not include any substantial service apart from possible sales consulting and support. Level 1 to 3 of the maturity model represent value-added services whereas level 4 and level 5 represent a degree of maturity, where service is an integrated or even the predominant part of the business model. The potential for strategic differentiation from competition (x-axis) but also the required capabilities and organisational skills (y-axis) gradually increase along the path of this maturity model.

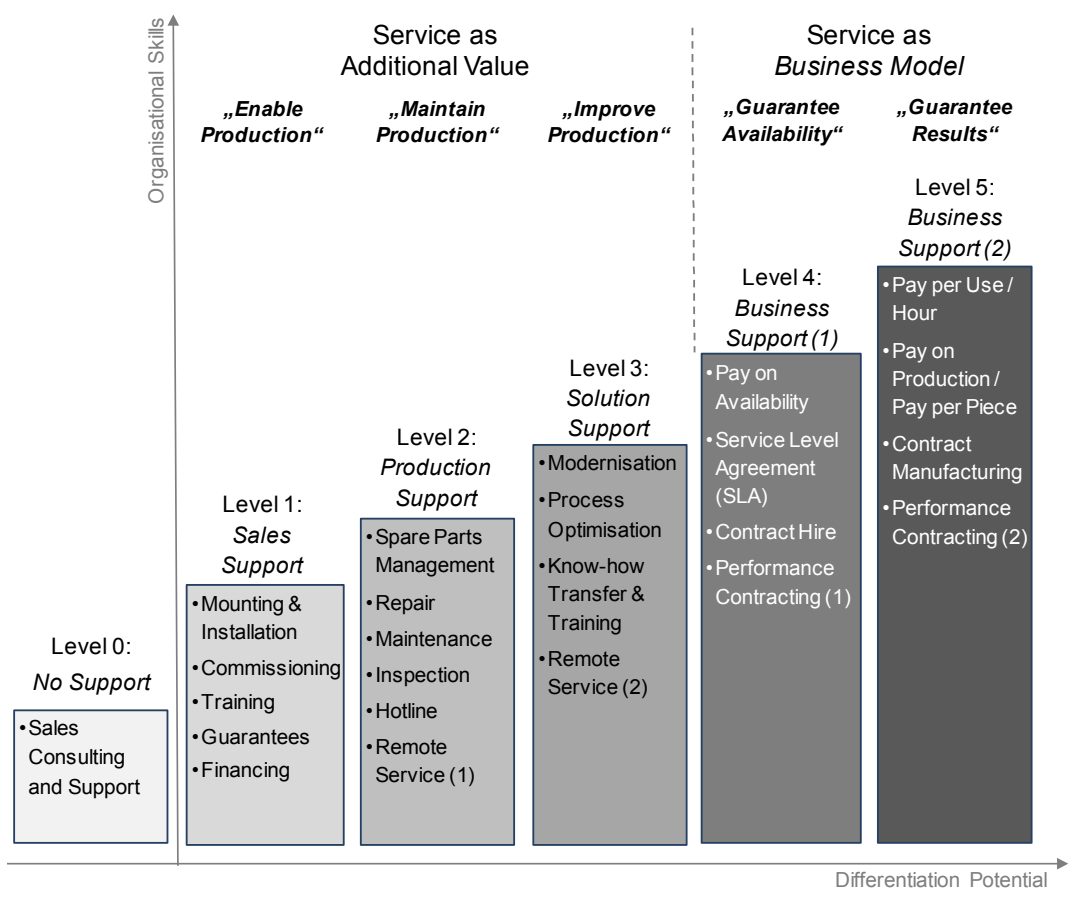

Figure 1. Service Maturity Model [24]. 
As shown in Figure 1, maturity level 1 comprises services, which facilitate the production of machines and plants at the customer's site. Fitting, construction and commissioning services as well as staff training may be required in this package. Offers of guarantees and financing options should further increase customer value, thus, providing sales support.

Level 2 services aim at supporting the production process or other core processes of the customer. They comprise classic services such as spare parts management, maintenance, repairs and inspection. Additionally, services on this level include remote services, such as support for remote-controlled failure analysis and system updates.

On level 3, the offered services are used to optimise the application and utilisation of machines and other technical equipment, thus reducing customers' cost [25]. This entails modernising plants with new components, optimising processes by means of lean production methods and improving know-how through training. Advanced remote services can help improve the availability and capacity of machines and plants. Applying predictive maintenance enables defective parts to be identified at an early stage by remote diagnosis and data analysis, thus, averting failures and shut downs through preventive maintenance [26]. Additionally, production data and parameters can be analysed and adapted remotely with the help of advanced analytics by the plant operator which, should further enhance performance [27] [28].

From level 4 onwards, product sales are not of primary interest anymore. Rather, it is the availability of the respective service for the customer. This service level is represented by business support (1), that offers services or hybrid products at a fixed leasing rate with a guaranteed performance standard, e.g. $98 \%$ plant availability, including full service for a defined period. The product itself remains the property of the manufacturer, who is, however, not responsible for operating the machine or staff deployment [26]. The usage fees charged for machines and plants are billed applying pay-on-availability models. Therefore, it is in the manufacturer's own best interest to keep the system operational at any time. These models provide customers with the advantage of not having to incur acquisition costs, which is particularly beneficial to small and medium-sized enterprises [26]. Contract hire describes a type of operational leasing of machines and plants and includes further services such as maintenance, carried out by the company leasing out the machine [29]. The required services are settled in Service Level Agreements (SLA) between the customer and the supplier. This includes a certain level of quality of service, responsibilities and liabilities [30]. Moreover, rights, obligations and legal consequences are documented by the cooperation partners in the event the SLA is breached [31].

On level 5 - business support (2) - the manufacturer provides the staff and operates the product/service. This includes responsibility and risk concerning operations like incorrect handling as well as responsibility for operation and maintenance cost. The customer is charged for actual usage. By paying on production or per piece, invoicing is separated from the physical asset and a fixed fee is charged for each unit produced. With this model, the manufacturer benefits from good product quality, low operation costs and highperformance rates of the plant or machine [26] [28]. In case of contract manufacturing (outsourcing), the customer transfers responsibility for the production of individual parts or the entire product completely to another company. This may be a manufacturer of the product or a logistics provider. Cooperation is subject to contractually regulated terms and conditions [32].

\subsection{Service Procedure Model}

A high level of maturity requires a systematic approach to service development and deployment, e.g. by applying a procedure model. Procedure models create a framework and define the phases and processes for service development and deployment. They range from finding ideas for new services to conceptualising and implementing a marketable service. Additionally, procedure models usually include tools and methods to be applied during the various phases [12] [33].

In the literature, there are three basic types of procedure models for developing and deploying services: the linear phase model, the iterative process model and the prototyping model [12]:

i. Linear Phase Model: According to this model, the individual phases are completed consecutively and chronologically within a defined structure. The output of one phase is the input of the next one and serves as a milestone or a so-called Quality Gate. The advantages of the linear model are a high degree of process transparency, result-orientation and the simplicity of the model. Lacking flexibility due to the rigid nature of the model without being able to go back to a preceding, already completed phase, is a disadvantage.

ii. Iterative Process Model: In this spiral model, the development phases are completed several times over. In a first iteration, a fine concept is derived from an initial draft of the service in question. In recurring reruns, changes and adaptations can be applied in each phase. The major advantage of this model is the ability to quickly reach initial results and to rectify errors. It must be noted, however, that the disadvantages are the high degree of complexity and required coordination efforts.

iii. Prototyping Model: In this model, a prototype of a service is developed in order to be tested by customers at an early stage and improved if required. The phases of the prototyping model overlap and cannot be distinguished from each other. The advantages of this model are the manifold fields of application, the support in communicating with customers and the possibility to consider customer requirements. A disadvantage is the effort required to coordinate and control the process. 
These procedure models commonly depict and describe the process of service development and deployment in a simplified manner during several different phases. Main phases usually describe the start or the initiative, the process of generating ideas for services, the analysis of requirements from a customer's and supplier's perspective. This is relevant for the assessment and implementation of service ideas, the conception phase as well as implementation and testing. Based on generic phases, specific models can be derived to continuously generate new ideas and transform them into marketable services.

During the research project with industrial partners in the field of mechanical and plant engineering and logistics, from the vast number of models available in literature one model is to be emphasised. The procedure model of Bullinger and Schreiner [33] has gained particularly strong acceptance and therefore, is applied for service development and deployment. As illustrated in Figure 2 this procedure model comprises six phases: (1) initial phase, (2) analysis phase, (3) conception phase, (4) preparation phase, (5) testing and (6) implementation phase.

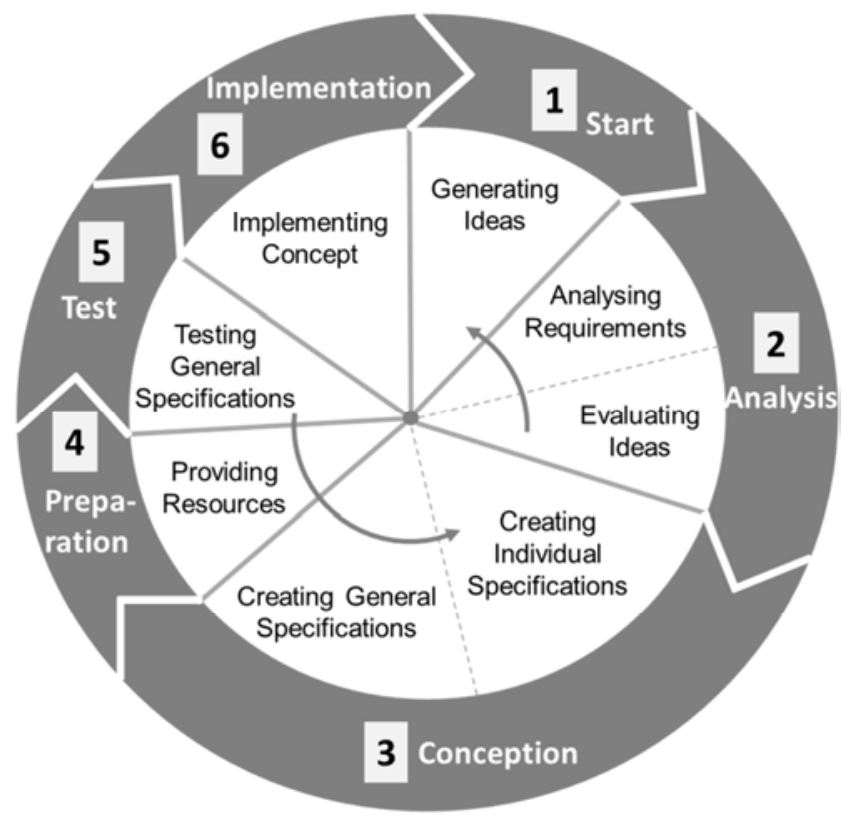

Figure 2. Service Procedure Model [33].

Ideas for new services are generated during the initial phase. The criteria for potential services are defined in the following analysis phase, which are to be considered for further planning of the service idea. The evaluation of individual ideas is also subject to these criteria, for instance, by using the method of a cost-benefit analysis. Should one draw the conclusion that implementing an idea is not feasible, e.g. due to costs being too high or the required technology not being sophisticated enough, this may lead to the regression of the service idea to the initial phase. Positively assessed service ideas proceed to the conception phase, where an extensive analysis is applied, covering relevant dimensions like resources, market aspects, processes and financial figures. The results from this analysis are then merged into a master plan. The resources required for the deployment of the service are provided in the preparation phase. During the subsequent testing phase, the overall specifications of a service (business model) are checked for potential flaws. Once the service has been approved, it enters the implementation phase before being launched on the market. The operational deployment of the service is continuously monitored, measuring key performance indicators like customer benefit and satisfaction or profitability. This type of monitoring is to ensure that obsolete services are replaced and potential for growth is facilitated by new services. Accordingly, innovative companies evaluate their procedure model continuously with iterative loops to generate new ideas and to transform them into marketable services.

\section{Conclusion}

New services are becoming increasingly important and strategically relevant for Austrian companies. Therefore, many companies have launched initial approaches to new service offerings, some already plan to expand and develop their service portfolio. However, many companies still face major challenges on their way to developing innovative services. Apart from a missing written strategy, the process of service development and deployment is very often triggered externally (by the customer), or accidentally, and in some cases it is not clearly defined. In order to generate extra profits and improve customer loyalty by introducing innovative services, a more creative and systematic approach to service development and deployment is required. This can be achieved by applying the concept of Service Engineering and the service procedure model presented in this paper. Finally, the service maturity model allows companies to assess their current status regarding their service portfolio and to derive consistent service strategies.

\section{References}

[1] Scheer, A.-W., Grieble, O., and Klein, R., Modellbasiertes Dienstleistungsmanagement. In: Bullinger, H. J., and Scheer, A.-W., Eds., Service Engineering - Entwicklung und Gestaltung innovativer Dienstleistungen, Berlin-Heidelberg, 2006, pp. 19-51.

[2] Cáceres, R., and Guzmán, J., Seeking an innovation structure common to both manufacturing and services. Service Business, Vol. 9 2015, Iss. 3, pp. 361-379.

[3] Velamuri, V. K., Neyer, A.-K., and Möslein, K. M., Hybrid value creation: a systematic review of an evolving research area. Journal für Betriebswirtschaft, Vol. 61 2011, Iss. 1, pp. 335 .

[4] Roth, A., and Möslein, K.-M., Produzenten als Dienstleister: Auf dem Weg zu interaktiven hybriden Wertschöpfungssystemen. In: Schuh, G., and Stich, V., Eds., Enterprise-Integration - Auf dem Weg zum kollaborativen Unternehmen, Berlin-Heidelberg, 2014, pp. 139-151. 
[5] Opresnik, D., and Taisch, M., The manufacturers value chain as a service - the case of remanufacturing. Journal of Remanufacturing, Vol. 5 2015, Iss. 1, Art. 2.

[6] Spath, D., and Demuß, L., Entwicklung hybrider Produkte Gestaltung materieller und immaterieller Leistungsbündel. In: Bullinger, H. J., and Scheer, A.-W., Eds., Service Engineering - Entwicklung und Gestaltung innovativer Dienstleistungen, Berlin-Heidelberg 2006, pp. 461-502.

[7] Fähnrich, K.-P., and Opitz, M., Service EngineeringEntwicklungspfad und Bild einer jungen Disziplin. In: Bullinger, H. J., and Scheer, A.-W., Eds., Service Engineering - Entwicklung und Gestaltung innovativer Dienstleistungen, Berlin-Heidelberg, 2006, pp. 85-112.

[8] Kelley, T., and Kelley, D., Creative Confidence - Unleashing the Creative Potential Within Us All, New York, 2013.

[9] Brown, T., and Katz, B., Change by Design - How design thinking can transform organizations and inspires innovation, New York, 2009.

[10] Richter, H.-M., Tschandl, M., Platsch, M., and Mallaschitz, Ch., Erfolg durch neue Services: Service Design \& Engineering - Methoden, Werkzeuge und Vorgehensweisen. Kapfenberg-Steyr, 2016.

[11] Velamuri, V.-K., Neyer, A.-K., and Möslein, K.-M., Hybrid Value Creation, Understanding the Value Creating Attributes. In: Böhmann, T., and Leimeister, J. M., Eds., Integration von Produkt \& Dienstleistungen - Hybride Wertschöpfung, Noderstedt, 2010, pp. 3-16.

[12] Leimeister, J.-M., Dienstleistungsengineering und management, Berlin-Heidelberg, 2012.

[13] Schuh, G., Gudergan, G., and Grefrath, C., Geschäftsmodelle für industrielle Dienstleistungen. In: Schuh, G., Guergan, G., and Kampker, A., Eds., Management industrieller Dienstleistungen, Berlin-Heidelberg, 2016, pp. 65-104.

[14] Bullinger, H.-J., and Scheer, A.-W., Service Engineering Entwicklung und Gestaltung innovativer Dienstleistungen. In: Bullinger, H. J., and Scheer, A.-W., Eds., Service Engineering - Entwicklung und Gestaltung innovativer Dienstleistungen, Berlin-Heidelberg, 2006, pp. 3-18.

[15] Bienzeisler, A., Gahle, B., and Schletz, A.-K., Industrie 4.0 Ready Services. In: Fraunhofer IAO, Vol. 2014. Stuttgart, 2014.

[16] NESSI Networked European Software and Services Initiative, Big Data - A New World of opportunities, NESSI-Big Data White Paper 12, 2012. Retrieved from http://www.nessieurope.eu/Files/Private/NESSI_WhitePaper_BigData.pdf [20 June 2016].

[17] BITKOM German Association for Information Technology, Telecommunications and New Media, Leitfaden: Management von Big-Data-Projekten, 2013. Retrieved from https://www.bitkom.org/Publikationen/2013/Leitfaden/Manag ement-von-Big-Data-Projekten/130618-Management-vonBig-Data-Projekten.pdf [20 June 2016].

[18] Brennan, S., Big Data and Analytics in Aftersales Service and Warranty. IDC-Community, 2013. Retrieved from https://idccommunity.com/manufacturing/manufacturing-valuechain/bigdataandanalyticsinaftersalesserviceandwarranty $\quad[24$ June 2016].
[19] Stricker, K., Wegener, R., and Anding, M., Big Data revolutioniert die Automobilindustrie, München-Zürich: Bain \& Company Germany, Inc., 2014. Retrieved from http://www.bain.de/Images/Bain-

Studie Big\%20Data\%20revolutioniert\%20die\%20Automobili ndustrie_FINAL_ES.pdf [21 June 2016].

[20] Fromme, T., CRTL-S - Passen Methoden, Softwaretools und IT-Infrastrukturen zusammen, kann Big Data Antworten auf die spannende Frage "Was wäre, wenn?" liefern - entlang der gesamten automobilen Wertschöpfungskette. Sonderedition automotive IT, 01/2013. Retrieved from http://www.automotiveit.eu/wp-

content/uploads/2013/09/Sonderheft_BigData.pdf [22 June 2016].

[21] Bergles, K., Intelligente Systeme zur Unterstützung von Produktions- und Servicepersonal, 2015. Retrieved from https://www.knapp.com/cms/cms.php?pageName=press\&iD= 142\&sid $=$ o19moilfoo5ph8k707m5duv016 [4 October 2016].

[22] Mettler, T., A design science research perspective on maturity models in information systems, Technical report BE IWIHNE-03. University of St. Gallen Report, 2009. Retrieved from

https://www.researchgate.net/profile/Tobias_Mettler/publicati on/44939433_A_Design_Science_Research_Perspective_on Maturity Models in Information Sytems/links/0deec $53 \overline{4} \mathrm{f} 9 \overline{2}$ 2e719c6000000.pdf [21 June 2016].

[23] Allweyer, T., and Knuppertz, T., EDEN - Reifegradmodell für Prozessmanagement: Prozessorientierung in Unternehmen, 2009. Retrieved from http://www.bpmmaturitymodel.com/eden/export/sites/default/de/Downloads/B PM_Maturity_Model_EDEN_White_Paper.pdf [13 March 2017].

[24] Richter, H. M., and Tschandl, M., Service Engineering - Neue Services erfolgreich gestalten und umsetzen. In: Bruhn, M., and Hadwich, K., Eds., Forum Dienstleistungsmanagement 2017 - Dienstleistungen 4.0, Wiesbaden, 2017, pp. 157-184.

[25] Osterwalder, A., and Pigneur, Y., Business model generation: A handbook for visionaries, game changers, and challengers. Hoboken, 2010.

[26] Schuh, G., Gudergan, G., Senderek, R., and Frombach, R., (2016), Service Engineering. In: Schuh, G., Guergan, G., and Kampker, A., Eds., Management industrieller Dienstleistungen, Berlin-Heidelberg, 2016, pp. 169-199.

[27] Emmrich, V., Döbele, M., Bauernhansl, T., Paulus-Rohmer, D., Schatz, A., and Weskamp, M., GeschäftsmodellInnovation durch Industrie 4.0 - Chancen und Risiken für den Maschinen- und Anlagenbau. München, 2015.

[28] Porter, M.-E., and Heppelmann, J.-E., Wie Smarte Produkte den Wettbewerb verändern. Harvard Business Manager, 12/2014, pp. 35-60.

[29] Boobyer, C., Leasing and Asset Finance - The Comprehensive Guide for Practitioners. London, 2003.

[30] Böhmann, T., and Krcmar, H. T., Modulare Servicearchitekturen. In: Bullinger, H. J., and Scheer, A.-W., Eds., Service Engineering - Entwicklung und Gestaltung innovativer Dienstleistungen, Berlin-Heidelberg, 2006, pp. 377-401.

[31] Haller, S., Dienstleistungsmanagement - Grundlagen Konzepte - Instrumente. Wiesbaden, 2015. 
[32] Kotabe, M., and Helsen, K., Global Marketing Management. Hoboken, 2011.

[33] Bullinger, H.-J., and Schreiner, P., Service Engineering: Ein Rahmenkonzept für die systematische Entwicklung von
Dienstleistungen. In: Bullinger, H. J., and Scheer, A.-W., Eds., Service Engineering - Entwicklung und Gestaltung innovativer Dienstleistungen, Berlin-Heidelberg, 2006, pp. 5384 . 